\title{
Evaluation of the relatedness of Brucella spp. and Ochrobactrum anthropi and description of Ochrobactrum intermedium sp. nov., a new species with a closer relationship to Brucella spp.
}

\author{
Julián Velasco, ${ }^{1}$ Conchi Romero, ${ }^{1}$ Ignacio López-Goñi, ${ }^{1}$ José Leiva, ${ }^{2}$ \\ Ramón Díaz ${ }^{1,2}$ and Ignacio Moriyón ${ }^{1}$
}

Departamento de

Microbiología, Universidad de Navarra, Aptdo 1771 and Servicio de Microbiología, Clínica Universitaria de Navarra², Pamplona, Spain
Author for correspondence: Ignacio Moriyón. Tel: +3448425600 . Fax: + 3448425649. e-mail:imoriyon@unav.es

The relatedness of Brucella spp. and Ochrobactrum anthropi was studied by protein profiling, Western blot, immunoelectrophoresis and 165 rRNA analysis. Whole-cell and soluble proteins of brucellae and 0 . anthropi showed serological cross-reactivities quantitatively and qualitatively more intense than those existing with similar extracts of Agrobacterium spp. Numerical analysis of Western blot profiles of whole-cell extracts showed that $O$. anthropi LMG 3301 was closer to Brucella spp. than to O. anthropi LMG 3331', a result not obtained by protein profiling. These differences were not observed by Western blot with soluble fractions, and immunoelectrophoretic analyses suggested that this was due to destruction of conformational epitopes in Western blot procedures with the subsequent simplification of antigenic profile. Analysis of the 165 rRNA sequences of strains previously used in the species definition confirmed that strain LMG 3301, and also LMG 3306, were closer to the brucellae, and that LMG $3331^{\top}$ was in a separate cluster. The LMG 3301 and the LMG $3331^{\top}$ clusters could also be separated by their different colistin sensitivity and by PCR with 165 rRNA Brucella primers, and both methods showed strains of both clusters among clinical isolates classified as $\boldsymbol{O}$. anthropi by conventional tests. These results and those of previous DNA-DNA hybridization studies [Holmes, B., Popoff, M., Kiredjian, M. \& Kersters, K. (1988). Int J Syst Bacteriol 38, 406-416] show that the LMG 3301 cluster and related clinical isolates should be given a new species status for which the name Ochrobactrum intermedium sp. nov. is proposed (type strain is LMG $3301^{\top}=$ NCTC $12171^{\top}=$ CNS 2-75').

Keywords: Brucella, Ochrobactrum, antigenic relatedness, 16S rRNA

\section{INTRODUCTION}

The $\alpha-2$ subclass of the class Proteobacteria includes plant and animal pathogens that are characteristically associated pericellularly or intracellularly with eukaryotic cells (in the case of Brucella, Bartonella and Agrobacterium spp., and the rickettsiae), plant endosymbionts (the rhizobia) and other bacteria, mostly

Abbreviation: IEP, immunoelectrophoresis.

The GenBank accession number for the sequence of LMG 3301 is $U 70978$. soil inhabitants (Moreno, 1992; Moreno et al., 1990; Yanagi \& Yamasoto, 1993).

Early antigenic studies have shown that the brucellae are a very homogeneous antigenic group (Díaz et al., 1966, 1968) and, consistent with this, DNA-DNA hybridization studies have shown that the classical nominal species (Brucella melitensis, Brucella abortus, Brucella suis, Brucella ovis, Brucella canis and Brucella neotomae) can be grouped into a single genomic species (B. melitensis) (Verger et al., 1985). Several groups of data (reviewed by Moreno, 1992) show that 
Ochrobactrum anthropi is the closest known relative of brucellae. Moreover, although a likely member of the microbiota of soil (Aguillera et al., 1993; Holmes et al., 1988), an increasing number of works report the isolation of $O$. anthropi from immunocompromised patients (Bizet \& Bizet, 1995; Brivet et al., 1993; Chang et al., 1996; Cieslak et al., 1992; Ezzedine et al., 1994; Grandsden \& Eykyn, 1992; Haditsch et al., 1994; Holmes et al., 1988) and preliminary data suggests that some strains can multiply within cultured epithelial cells (E. Moreno, J. Velasco \& I. Moriyón, unpublished results). Therefore, $O$. anthropi and Brucella spp. show a different degree of interaction with eukaryotic cells and provide a model for comparative studies which could shed light on the adaptations to intracellular life in the $\alpha-2$ subclass. However, as presently defined, $O$. anthropi is heterogeneous: on the basis of a classical phenotypical characterization, three different biotypes (A, C and D corresponding to the former Achromobacter biotypes $\mathrm{A}, \mathrm{C}$ and $\mathrm{D}$ of $\mathrm{CDC} \mathrm{Vd}$ ) have been proposed (Holmes et al., 1988), and DNA-DNA hybridization studies show the existence of two groups of strains (Holmes et al., 1988) (thereafter referred to as hybridization groups 1 and 2) which would grant the definition of a new genomic species. In the present study, we have assessed the relatedness of Brucella and $O$. anthropi by whole-cell protein profiling, immunological methods and $16 \mathrm{~S}$ rRNA sequence analysis. This polyphasic approach (Vandamme et al., 1996) was chosen because, in addition to its taxonomic value, it could lead to identification of antigenically relevant proteins useful in further clinical (Velasco et al., 1997) and comparative molecular work. The results show a heterogeneity for $O$. anthropi that further supports the definition of a new species for hybridization group 2, and demonstrate that the brucellae are closer to this group than to hybridization group 1 which includes the $O$. anthropi type strain.

\section{METHODS}

Bacterial strains and growth conditions. The bacterial strains used are presented in Table 1 . For cell fractionation, $B$. melitensis $115, B$. abortus RB51, $O$. anthropi LMG 3301 and $3331^{\mathrm{T}}$, and Escherichia coli were grown in a peptone-glucose broth supplemented with $0.01 \%$ antifoam A/butyl acetate $(1: 3)$ (Sigma) in a fermenter (Aragón et al., 1996). B. ovis REO 198 and $B$. suis 2 were grown in tryptic soy broth (Difco) with or without $2.5 \%$ yeast extract, respectively, in 21 flasks on an orbital shaker. The agrobacteria were grown in $1.3 \%$ tryptose (Merck), $1.0 \%$ yeast extract (Merck), $0.1 \%\left(\mathrm{NH}_{4}\right)_{2} \mathrm{SO}_{4}, 0.03 \% \mathrm{NaH}_{2} \mathrm{PO}_{4}$ and $1.6 \%$ glucose in 21 flasks on an orbital shaker at $26^{\circ} \mathrm{C}$. In each case, cells were collected $(7000 \mathrm{~g}, 15 \mathrm{~min})$ and washed twice with $0.8 \% \mathrm{NaCl}$ [virulent Brucella strains were inactivated with phenol $\left(0.5 \%, 37^{\circ} \mathrm{C}, 48 \mathrm{~h}\right)$ before harvesting] for cell fractionation. For immunizations, bacteria were grown in Roux flasks containing the above-described media plus $1.5 \%$ agar, collected, washed twice with sterile saline $(7000 \mathrm{~g}, 15 \mathrm{~min})$, and then acetone-dried (Díaz et al., 1966). For protein analysis by SDS-PAGE bacteria were grown on the same solid media in Petri dishes. For DNA extraction, the $O$. anthropi strains were grown in tryptic soy agar (Difco) for $24 \mathrm{~h}$ at $37^{\circ} \mathrm{C}$.

\section{Bacterial fractions}

(i) Whole-cell protein extracts. Cells were resuspended in $1 \%$ SDS, $0.7 \mathrm{M}$ 2-mercaptoethanol, $10 \%$ glycerol, $10 \mathrm{mM}$ Tris $/ \mathrm{HCl}\left(\mathrm{pH} \mathrm{6.8)}\right.$, extracted at $100{ }^{\circ} \mathrm{C}$ for $10 \mathrm{~min}$ and cell debris removed by centrifugation $(12000 \mathrm{~g}, 10 \mathrm{~min})$. Duplicate extracts of two independently grown batches of cells were prepared to check the reproducibility of the results.

(ii) Soluble fractions. Cells were disintegrated in the presence of nucleases in a $40 \mathrm{~K}$ French Pressure Cell Press (SLM Instruments), and the soluble fraction was obtained by ultracentrifugation (supernatant) and characterized on the basis of the distribution of cytoplasmic and cell envelope markers as described previously (Moriyón \& Berman, 1982). For SDS-PAGE and Western blot (see below), the soluble fractions were resuspended in $1 \%$ SDS, $0.7 \mathrm{M} 2-$ mercaptoethanol, $10 \%$ glycerol, $10 \mathrm{mM}$ Tris $/ \mathrm{HCl}(\mathrm{pH} \mathrm{6.8)}$. Duplicates of the fractions were prepared to assess reproducibility.

(iii) Genomic bacterial DNA. DNA was obtained as described previously with minor modifications (Romero et al., 1995). Briefly, cells were suspended in $50 \mathrm{mM} \mathrm{NaCl}, 125 \mathrm{mM}$ EDTA, $50 \mathrm{mM}$ Tris $/ \mathrm{HCl}(\mathrm{pH} \mathrm{7.6)}$, heat-killed, and then disrupted by incubation with SDS and proteinase K. After precipitation of unwanted materials with $5 \mathrm{M} \mathrm{NaCl}$ and hexadecyltrimethylammonium bromide $(\mathrm{CTAB}) / \mathrm{NaCl}$, the DNA was extracted with phenol/chloroform/isoamyl alcohol, precipitated with 2-propanol, washed with $70 \%$ ethanol and dissolved in sterile distilled water.

SDSPAGE and numerical analysis. Whole-cell extracts and soluble fractions were analysed by SDS-PAGE (Pot et al., 1994), and gels were stained with Coomassie Blue and scanned using a ScanJet IIcx scanner (Hewlett Packard). The normalized densitometric traces of the electrophoretic patterns were grouped by performing a numerical analysis using the GelCompar 3.1 software package (Vauterin \& Vauterin, 1992). The level of similarity between each pair of traces was expressed as the Pearson product-moment correlation coefficient $(r)$, which for convenience was converted to a percentage (Pot et al., 1994). The levels of similarity between duplicate protein patterns were at least $90 \%$.

\section{Serological analyses}

(i) Immunoelectrophoresis (IEP). IEP was carried out in $1.8 \%$ Indubiose (IBF-Biotechnics, Villeneuve la Garenne, France), $0.05 \% \mathrm{NaN}_{3}, 0.04 \mathrm{M}$ sodium diethylbarbiturate/ $\mathrm{HCl}\left(\mathrm{pH} \mathrm{8.6)}\right.$ at $6 \mathrm{~V} \mathrm{~cm}^{-1}$ for $2 \mathrm{~h}$ (Díaz et al., 1966). After diffusion of the sera and immunoprecipitation $(18 \mathrm{~h}$ at $25^{\circ} \mathrm{C}$ ), the plates were soaked for $24 \mathrm{~h}$ in saline, washed with distilled water for $24 \mathrm{~h}$, air-dried and then stained with $1 \%$ Coomassie R-Blue in water/ethanol/acetic acid $(9: 2: 9$, by vol.).

(ii) Western blot. After SDS-PAGE, proteins were electroblotted on Immobilon P (Millipore) using a Trans-Blot SD apparatus (Bio-Rad) according to the instructions of the manufacturers. After overnight incubation in $0.15 \%$ Tween 20/10 mM PBS (pH 7.2) (PBS-Tween) supplemented with $3 \%$ skimmed milk, the blots were washed four times with PBS-Tween and incubated at room temperature with the appropriate serum diluted in PBS-Tween. After a new series of PBS-Tween washings, IgG was detected with peroxidaseconjugated Protein G (Pierce) $\left(2 \mu \mathrm{g} \mathrm{ml}^{-1}\right.$ in PBS-Tween) and 
Table 1. Bacterial strains

\begin{tabular}{|c|c|c|}
\hline Strain* & Relevant details & Reference \\
\hline A. radiobacter ICMP 10854 & Isolated from osier & This work \\
\hline A. rhizogenes IVIA 020-AP & Isolated from peachtree & This work \\
\hline A. vitis IVIA $565-5$ & Isolated from vine & This work \\
\hline B. abortus US19 & Attenuated vaccine strain & Alton et al. (1988) \\
\hline B. abortus 2308 & Virulent challenge strain, biotype 1 , serotype A & $\begin{array}{l}\text { García-Carillo \& Casa- } \\
\text { Olascoaga (1977) }\end{array}$ \\
\hline B. abortus RB51 & Rough mutant of B. abortus 2308 & Schurig et al. (1991) \\
\hline B. abortus $45 / 20$ & Rough mutant of $B$. abortus $45 / 0$ & McEwen (1940) \\
\hline B. melitensis 115 & Rough mutant directly isolated from goat & Alton et al. (1988) \\
\hline B. ovis Reo 198 & $\begin{array}{l}\text { Naturally rough Brucella species, } \mathrm{CO}_{2}^{-} \\
\text {independent strain }\end{array}$ & Alton et al. (1988) \\
\hline B. suis 2 & Attenuated vaccine strain, biovar 1 & Xin (1986) \\
\hline B. suis 1330 & $\begin{array}{l}\text { Virulent, reference strain of biotype 1, serotype } \\
\text { A }\end{array}$ & Alton et al. (1988) \\
\hline E. coli NCTC 8007 & O111 K58H2, enteropathogenic & $\begin{array}{l}\text { Griffiths \& Humphreys } \\
\text { (1978) }\end{array}$ \\
\hline O. anthropi LMG $3331^{\mathrm{T}}$, CIP $149 \cdot 70$ & $\begin{array}{l}\text { Type strain, DNA-DNA hybridization group } 1 \text {, } \\
\text { unknown origin }\end{array}$ & Holmes et al. (1988) \\
\hline O. anthropi LMG 3310 , CNS 4-78 & $\begin{array}{l}\text { DNA-DNA hybridization group 1, isolated } \\
\text { from faeces }\end{array}$ & Holmes et al. (1988) \\
\hline O. anthropi LMG 3329, CIP 81-74 & $\begin{array}{l}\text { DNA-DNA hybridization group } 1 \text {, isolated } \\
\text { from abscess }\end{array}$ & Holmes et al. (1988) \\
\hline O. anthropi LMG 2320 , NCIB 8688 & $\begin{array}{l}\text { DNA-DNA hybridization group 1, isolated } \\
\text { from arsenic-containing cattle-dipping fluid }\end{array}$ & Holmes et al. (1988) \\
\hline O. anthropi LMG 3309, CNS 7-77 & $\begin{array}{l}\text { DNA-DNA hybridization group 1, isolated } \\
\text { from human ear discharge }\end{array}$ & Holmes et al. (1988) \\
\hline O. anthropi LMG 3301, CNS 2-75 & $\begin{array}{l}\text { DNA-DNA hybridization group 2, isolated } \\
\text { from human blood }\end{array}$ & Holmes et al. (1988) \\
\hline O. anthropi LMG 3306, CNS 23-76 & $\begin{array}{l}\text { DNA-DNA hybridization group 2, isolated } \\
\text { from soil }\end{array}$ & Holmes et al. (1988) \\
\hline O. anthropi CUN 559 & Clinical isolate from human blood & This work \\
\hline O. anthropi CUN 2944 & Clinical isolate from human blood & This work \\
\hline O. anthropi CUN 6130 & Clinical isolate from human blood & This work \\
\hline O. anthropi CUN 9446 & Clinical isolate from human blood & This work \\
\hline O. anthropi CUN 11040 & Clinical isolate from human blood & This work \\
\hline
\end{tabular}

* CIP, Collection de l'Institut Pasteur, Paris, France; CNS, Centre National des Salmonella, Paris, France; CUN, Clínica Universitaria, Universidad de Navarra, Pamplona, Spain; ICMP, International Collection of Microorganisms from Plants, Auckland, New Zealand; IVIA, Instituto Valenciano de Investigación Agrarias, Valencia, Spain; LMG, Culture Collection of the Laboratory for Microbiology, Ghent, Belgium; NCIB, National Collection of Industrial and Marine Bacteria, Torry Research Station, Aberdeen, UK; NCTC, National Collection of Type Cultures, Central Public Health Laboratory, London, UK.

blots developed with 4-chloro-1-naphthol $/ \mathrm{H}_{2} \mathrm{O}_{2}$ (Hawkes et al., 1982). The normalized densitometric traces of the blots were obtained and analysed as described above for the SDSPAGE protein patterns. For a given extract or fraction, the sera used in the analysis were those showing the maximal reactivity with the homologous antigen.

(iii) Immune sera. White New Zealand rabbits were hyperimmunized with acetone-dried cells of $B$. abortus RB51, $B$. melitensis 115, B. suis 1330, B. ovis REO 198, A. radiobacter ICPB $10854, A$. rhizogenes IVIA 020-AP, $A$. vitis IVIA 5655, O. anthropi LMG $3331^{\mathrm{T}}$ and 3301 , and $E$. coli $\mathrm{O} 111$ as described previously (Díaz et al., 1966). Controls performed with sera taken before immunizations showed no reactivity in any of the immunological tests.

\section{$16 S$ rRNA analysis}

(i) PCR with Brucella primers. The oligonucleotide primers, selected from the 16S rRNA sequence of $B$. abortus previously published (Dorsch et al., 1989), were F4 (5'TCGAGCGCCCGCAAGGG-3') and R2 (5'-AACCATAGTGTCTCCACTAA-3'), and the PCR assay was performed as described in previous works (Romero et al., 1995). Positive controls contained $80 \mathrm{ng}$ B. abortus 2308 DNA as template, and negative controls consisted of sterile water instead of DNA template. Generally recommended procedures were used to avoid contamination (Rolfs et al., 1992), and each sample was tested at least in triplicate.

(ii) PCR amplification, cloning and sequencing of the 165 rDNA genes. Approximately $0 \cdot 1 \mu \mathrm{g}$ bacterial DNA was used as a PCR 


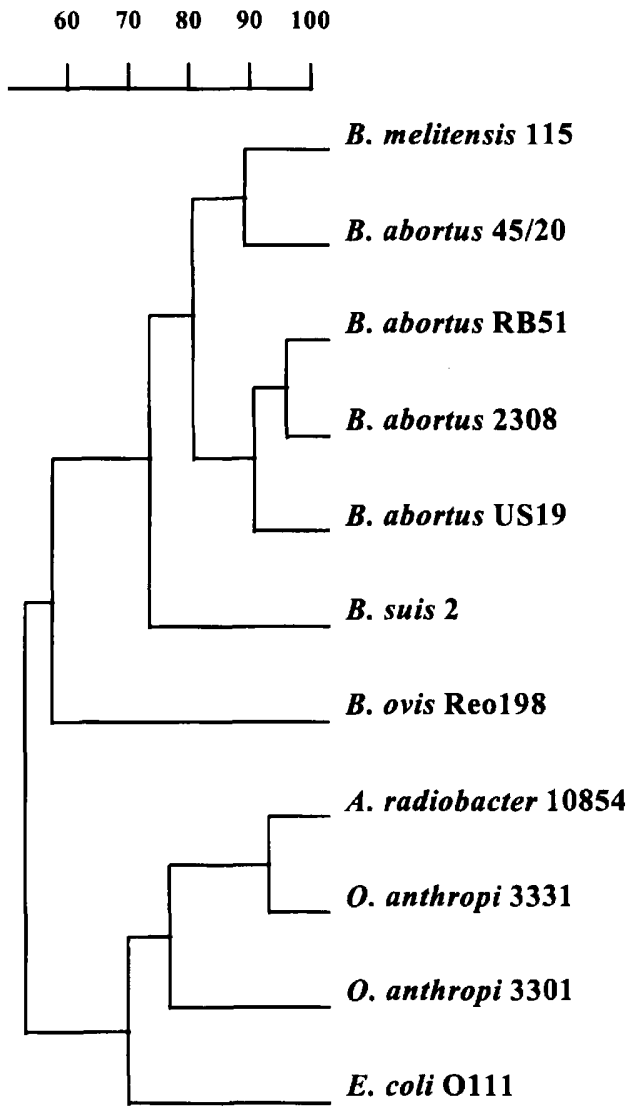

Fig. 1. Dendrogram derived from unweighted pair group average linkage of correlation coefficients for the protein patterns of the indicated strains.

template with primers $\mathrm{fD} 1$ and $\mathrm{rD} 1$ to amplify the entire $16 \mathrm{~S}$ rRNA gene (Weisburg et al., 1991). Amplifications were performed in a $100 \mu \mathrm{l}$ reaction mixture containing each of the dNTPs at a concentration of $200 \mu \mathrm{M}$, each of the primers at a concentration of $0.5 \mu \mathrm{M}$, and $5 \mathrm{U}$ Taq DNA polymerase (Promega). The $\mathrm{Mg}^{2+}$ concentration was optimized at $1.5 \mathrm{mM} \mathrm{MgCl}_{2}$. Other PCR conditions were: 35 cycles consisting of $1 \mathrm{~min}$ at $95^{\circ} \mathrm{C}, 2 \mathrm{~min}$ at $60^{\circ} \mathrm{C}$, and $4 \mathrm{~min}$ at $72^{\circ} \mathrm{C}$, plus an additional cycle with a $10 \mathrm{~min}$ chainelongation step. Amplifications were performed with a GeneAmp Amplification System 2400 kit (Perkin-Elmer).

Amplified DNA was analysed by electrophoresis on a $0.8 \%$ agarose gel ( $100 \mathrm{~V}$ for $30 \mathrm{~min}$ ) and visualized by ethidium bromide staining. The amplified DNA was re-electrophoresed on a $0.7 \%$ low-melting-point agarose gel (Hispanlab) and purified with Wizard PCR Preps DNA Purification System (Promega). This DNA was then cloned in the pMOSBlue T-vector (Amersham) following the manufacturer's instructions. The resulting recombinant plasmids were transformed and amplified in competent $E$. coli MOSBlue, subsequently purified with the Wizard Minipreps DNA Purification System (Promega) and sequenced by using a Thermo Sequenase fluorescent cycle sequencing kit (Amersham). The sequencing primers were the following forward and reverse internal primers (Edwards et al., 1989): pC (positions 342-361; E. coli 16S rRNA sequence numbering), $\mathrm{pE}$ (positions 907-926), $\mathrm{pD}$ (positions
536-519), and $\mathrm{pF}$ (positions 1030-1054). In addition, M13 forward and reverse primers were used to determine the sequences of both ends of the cloned 16S rDNA gene. The sequencing reactions were analysed with an ALF DNA sequencer (Pharmacia).

(iii) Phylogenetic analysis of $16 \mathrm{~S}$ rRNA sequences. The $16 \mathrm{~S}$ rRNA sequences of appropriate members of the $\alpha-2$ subclass of the Proteobacteria [obtained from the GenBank (see below)] and those obtained for $O$. anthropi LMG strains $2320,3301,3306,3309,3310,3329$ and $3331^{\mathrm{T}}$ were aligned by using the GENEWORK program (version $2.45 \mathrm{n}$ ). The PHYLIP package (Felsenstein, 1993) was used for the evolutionary tree inference. Positions of sequence and alignment uncertainty were omitted from the analysis, and the pairwise evolutionary distances for 1250 nucleotides were computed by using the Jukes-Cantor correction calculated with the DNADIST program. Phylogenetic relationships were inferred by using the neighbour-joining (NEIGHBOR), FitchMargoliash (FITCH), maximum-parsimony (DNAPARS) and maximum-likelihood (DNAML) algorithms. The resulting unrooted tree topologies were evaluated by bootstrapping of the neighbour-joining method data based on 500 resamplings and using the following programs: SEQBOOT, DNADIST, NEIGHBOR-JOINING and CONSENSE.

Nucleotide sequence accession numbers. The accession numbers for the nucleotide sequences (taken from GenBank) are: D12794 for $O$. anthropi LMG $3331^{\mathrm{T}}$; U70978 for $O$. anthropi LMG 3301; U88440 for $O$. anthropi LMG 3306; U88441 for $O$. anthropi LMG 3309; U88442 for $O$. anthropi LMG 3310; U88443 for $O$. anthropi LMG 3329; and U88444 for $O$. anthropi LMG 2320; D12788 for Agrobacterium rhizogenes IAM $13570^{\mathrm{T}}$; D12784 for Agrobacterium tumefaciens IAM $13129^{\mathrm{T}}$; D12795 for Agrobacterium vitis IAM 14140; X13695 for Brucella abortus NCBI 39330; L37584 for Brucella canis ATCC 23365 ; L26166 for Brucella melitensis ATCC ${ }^{\mathrm{T}}$ 23456; L26169 for Brucella neotomae ATCC $23459^{\mathrm{T}}$; L26168 for Brucella ovis ATCC $25840^{\mathrm{T}}$; L26169 for Brucella suis ATCC $23444^{\mathrm{T}}$; D12786 for Mycoplana dimorpha IAM 13154; D12789 for Phyllobacterium myrsinacearum IAM 13584; D12790 for Phyllobacterium rubiacearum IAM 13587; Z70003 for Bartonella bacilliformis LA6.3; M73229 for Bartonella (Rochalimaea) henselae ATCC $49882^{\mathrm{T}}$; M73228 for Bartonella (Rochalimaea) quintana ATCC VR $-358^{\mathrm{T}}$; and M73230 for Bartonella (Rochalimaea) vinsonii ATCC VR-152 ${ }^{\mathrm{T}}$.

Conventional phenotypical characterization. The API $20 \mathrm{NE}$ (bioMérieux), GNI (bioMérieux Vitek) and BBL Crystal E/NF (BBL Microbiology Systems) systems were used to investigate the response of the $O$. anthropi strains in conventional phenotypical tests. The presence and position of flagella was determined by electron microscopy. Susceptibility to amoxicillin, ampicillin/clavulanic acid, aztreonam, ceftazidime, ceftriaxone, cephalotin, chloramphenicol, piperacillin, gentamicin, ofloxacin and trimethoprim/sulfamethoxazole was assessed on MuellerHinton agar using the standardized disk diffusion test (Bauer et al., 1966) with antibiotic disks of commercial origin (Difco). Interpretative criteria for zone diameters for the above antimicrobial agents were those recommended by the NCCLS (National Committee for Clinical Laboratory Standards, 1997). Susceptibility to polymyxin B and colistin was also tested by the disk diffusion method with either commercial disks $(10 \mu \mathrm{g}$ per disk; Difco) or sterile disks (Difco) loaded with 10-50 $\mu \mathrm{g}$ polymyxin B (Sigma; $7000 \mathrm{U}$ $\mathrm{mg}^{-1}$ ). Since there is no correlation between sensitivity and 
size diameter for these antibiotics (Bauer et al., 1966), the results were interpreted as sensitivity or resistance on the basis of the presence or complete absence of an inhibition halo.

\section{RESULTS}

\section{SDSPAGE of whole-cell protein extracts}

The dendrogram obtained after numerical analysis of the whole-cell protein patterns of the bacteria studied (Fig. 1) shows that two separate clusters were differentiated. One cluster comprised all Brucella strains, with $B$. abortus in a position closer to B. melitensis than to $B$. suis and $B$. ovis. A second cluster grouped the two $O$. anthropi strains representative of hybridization groups 1 (LMG 3331 ${ }^{\mathrm{T}}$ ) and 2 (LMG 3301) with $A$. radiobacter ICPB 10854 . According to this analysis, $O$. anthropi LMG $3331^{\mathrm{T}}$ was closer to $A$. radiobacter 10854 than to $O$. anthropi LMG 3301.

\section{Serological cross-reactivity}

(i) Whole-cell proteins. Representative results of the Western-blot analyses of whole-cell protein extracts are presented in Fig. 2. As expected, a strong reactivity was observed with the sera and the homologous antigens (Fig. 2a, lane 6, and Fig. 2b, lanes 1-4). Although a marked heterologous cross-reactivity was observed with the serum to $O$. anthropi $\mathrm{LMG} 3301$ and Brucella whole-cell extracts (Fig. 2a, lanes 1-4), this serum showed only a weak reactivity with the extracts of $O$. anthropi LMG $3331^{\mathrm{T}}$ (Fig. 2a, lane 5) and $A$. radiobacter ICPB 10854 (Fig. 2a, lane 7) of intensity comparable to that obtained with E. coli extracts (Fig. $2 \mathrm{a}$, lane 8). Moreover, numerical analysis of the banding patterns grouped strain LMG 3301 with the brucellae, and strain LMG $3331^{\mathrm{T}}$ with $A$. radiobacter (Fig. 2a). Western blots with the antiserum to $B$. suis and the corresponding numerical analysis (Fig. 2b) confirmed the above results with respect to the in-
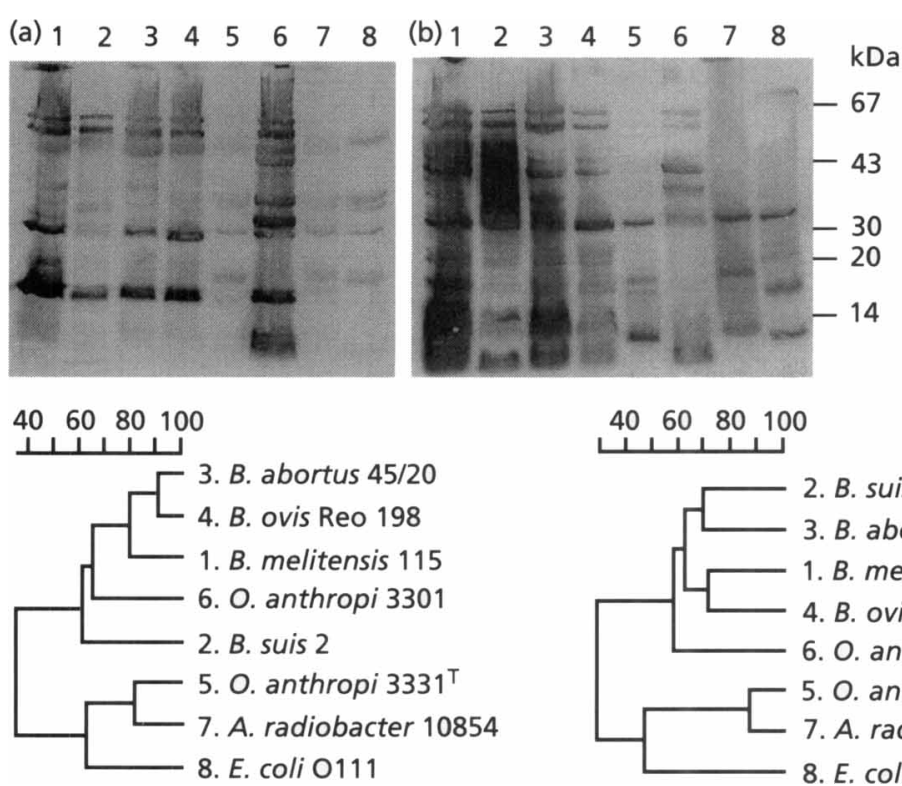
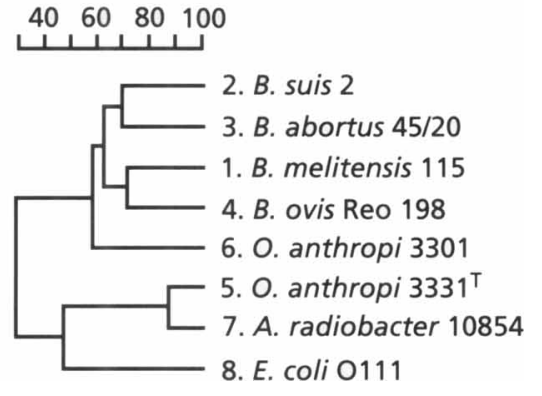

Fig. 2. Western-blot analyses of whole-cell protein antigens detected with sera from rabbits hyperimmunized with $O$. anthropi 3301 (a) and B. suis 1330 (b). The dendrograms derived from unweighted pair group average linkage of correlation for the corresponding banding patterns are shown below. Numbers given in the dendrogram for the bacteria analysed correspond to those of the Western blot lanes.

Table 2. Number of precipitation lines by IEP with cytosols and hyperimmune sera

\begin{tabular}{|c|c|c|c|c|c|c|c|c|}
\hline \multirow[t]{2}{*}{ Cytosol of: } & \multicolumn{8}{|c|}{ Sera to: } \\
\hline & 2 & 3 & 5 & 6 & 7 & 8 & 9 & 10 \\
\hline 1 B. ovis Reo 198 & $>10$ & $>10$ & 6 & 8 & 1 & 3 & 3 & 0 \\
\hline 2 B. abortus RB51 & $>10$ & $>10$ & 6 & 6 & 0 & 2 & 2 & 0 \\
\hline 3 B. melitensis 115 & $>10$ & $>10$ & $>10$ & $>10$ & 2 & 1 & 3 & 0 \\
\hline 4 B. suis 1330 & $>10$ & $>10$ & $>10$ & $>10$ & 2 & 2 & 3 & 0 \\
\hline 5 O. anthropi LMG 3301 & 6 & $>10$ & $>10$ & $>10$ & 6 & 3 & 5 & 0 \\
\hline 6 O. anthropi LMG $3331^{\mathrm{T}}$ & 5 & $>10$ & $>10$ & $>10$ & $>10$ & 5 & 4 & 0 \\
\hline 7 A. radiobacter 10854 & 0 & 1 & 0 & 0 & $>10$ & 4 & 5 & 0 \\
\hline 8 A. rhizogenes 020 -AP & 0 & 1 & 0 & 0 & 6 & $>10$ & 5 & 0 \\
\hline 9 A. vitis $565-5$ & 0 & 2 & 1 & 3 & $>10$ & $>10$ & $>10$ & 0 \\
\hline 10 E. coli $\mathrm{O} 111$ & 0 & 0 & 0 & 1 & 0 & 0 & 0 & $>10$ \\
\hline
\end{tabular}




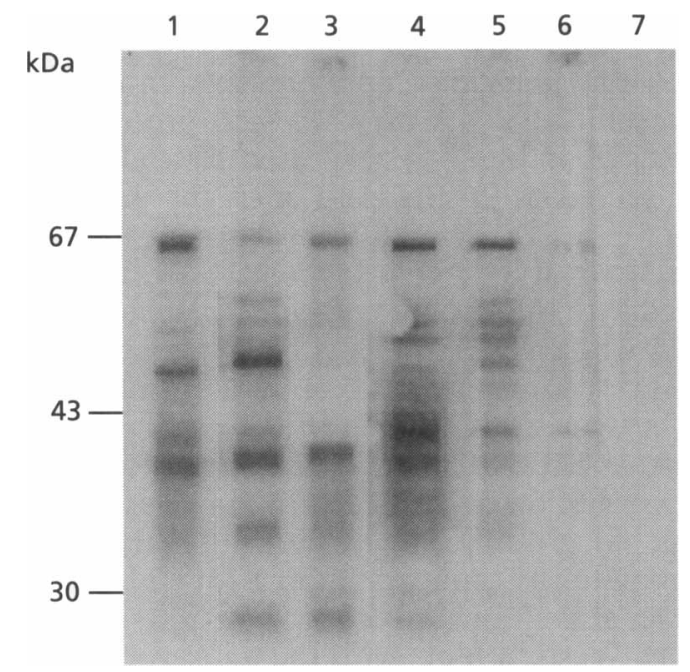

Fig. 3. Western-blot analyses of soluble fraction antigens detected with sera from rabbits hyperimmunized with 0 . anthropi 3301. The dendrogram derived from unweighted pair group average linkage of correlation for the corresponding banding patterns is shown below. Numbers given in the dendrogram for the bacteria analysed correspond to those of the Western blot lanes.

tensity of the cross-reactivities and the similarities and differences in banding patterns.

(ii) Soluble fraction proteins. More than 10 antigenic components were clearly resolved in the homologous native soluble fractions by IEP, with electrophoretic mobilities varying from markedly anodic to slightly cathodic (not shown), and heterologous crossreactivities of various degrees were also observed. Table 2 presents a quantitative summary of these results, and according to this simple criterion $O$. anthropi $\mathrm{LMG} 3331^{\mathrm{T}}$ and LMG 3301 were closer to the brucellae than to the agrobacteria. As reported before (Díaz et al., 1966, 1968), cross-absorptions did not allow a clear identification of Brucella species-specific antigens (not shown) and similar cross-absorptions did not allow the identification of strain-specific antigens for $O$. anthropi LMG $3331^{\mathrm{T}}$ and LMG 3301 (not shown). Consistent with similar absorptions performed with sera from $B$. melitensis-infected goats (Velasco et al., 1997), Brucella-Ochrobactrum crossabsorption experiments with the soluble fractions showed genus-specific antigens for both (not shown). Western blots with the same sera and fractions revealed fewer antigenic components than the IEP in both the homologous and heterologous tests (results with the $O$. anthropi LMG 3301 antiserum are presented in Fig. 3 ), but they showed clear differences between $O$. anthropi $\mathrm{LMG} 3331^{\mathrm{T}}$ and LMG 3301 (Fig. 3, lanes 1 and 2), and also differences and similarities with the brucellae (lanes 3, 4 and 5). However, numerical analysis of the banding patterns did not resolve the LMG $3331^{\mathrm{T}}$ and LMG 3301 strains and the Brucella spp. (Fig. 3). By both IEP (Table 2) and Western blot (Fig. 3, lane 6), the cross-reactivity with $A$. radiobacter soluble fraction was weak, and no reactivity was observed with similar $E$. coli fractions (Table 2 and Fig. 3, lane 7).

\section{$16 S$ rRNA analysis}

The above results showed the heterogeneity of two strains presently included in $O$. anthrop $i$ and suggested a closer relationship between strain LMG 3301 and the brucellae closer than that existing with $O$. anthropi LMG $3331^{\mathrm{T}}$. To confirm and extend these results, the 16S rRNA genes of several of the strains (LMG 3301, $3306,3310,3329$ and 2320) used to define $O$. anthropi (Holmes et al., 1988) were amplified, cloned and sequenced. These sequences plus those of $O$. anthropi LMG $3331^{\mathrm{T}}$ and representative species of the $\alpha-2$ subclass (all taken from GenBank) were analysed after omitting hypervariable regions and uncertain or ambiguous nucleotide positions of the complete $16 \mathrm{~S}$ rDNA sequences [1250 nucleotides between $E$. coli positions 29 and 1539 (Brosius et al., 1978)]. The sequence similarity matrix obtained by the JukesCantor correction showed that distances between the Brucella spp. and strains LMG 3301 and 3306 (from 98.96 for B. neotomae to 99.28 for B. canis and B. suis) were always below distances found between Brucella spp. and the $O$. anthropi LMG $3331^{\mathrm{T}}$ cluster (LMG $3309,3310,3329$ and 2320 ) (from 98.40 for B. ovis to 98.64 for B. canis and B. suis). Moreover, the Brucella$O$. anthropi LMG 3301 and 3306 distance (see above) was shorter than that existing between the $O$. anthropi LMG $3331^{\mathrm{T}}$ and LMG 3301 clusters (from 98.08 to 98.56). The evolutionary trees obtained with all four algorithms (neighbour-joining, Fitch-Margoliash, maximum-parsimony and maximum-likelihood) were similar. Fig. 4 shows the neighbour-joining tree based on nearly complete $16 \mathrm{~S}$ rDNA sequences. The confidence limit for each group, as determined by the bootstrap method with 500 resamplings, was more than $50 \%$ for most of the nodes, except for the internode connecting the tree with branches of the group containing $M$. dimorpha and the members of the genera Bartonella and Phyllobacterium, which was $37 \%$. Bootstrap probabilities for the BrucellaOchrobactrum groups were more than $95 \%$ indicating that the location of the resulting three clusters (Fig. 4) was consistent. The confidence limits of the terminal nodes within each of these groups varied between 27 


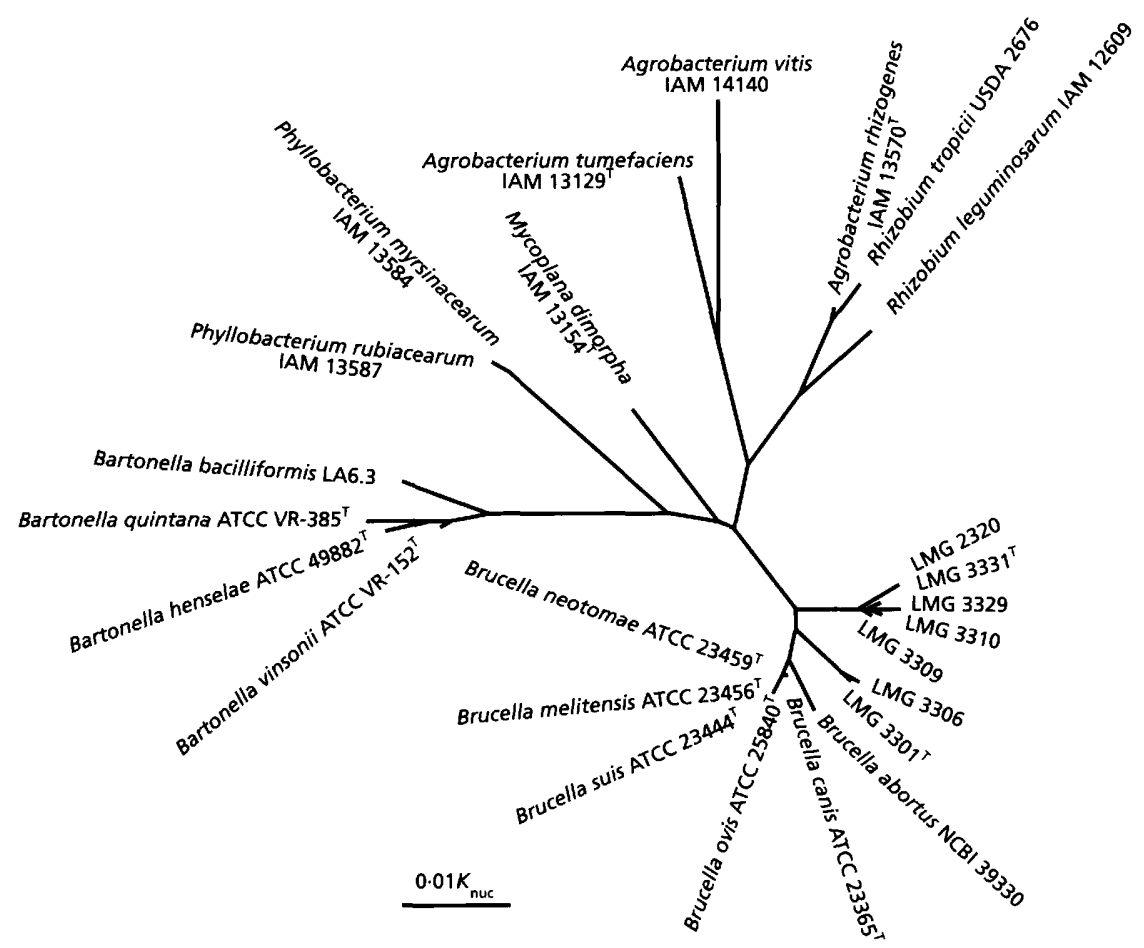

Fig. 4. Unrooted evolutionary tree showing the relationships of Brucella, Ochrobactrum and several members of the $\alpha-2$ subclass of the class Proteobacteria. The tree was inferred from 1250 nucleotide positions by using the Jukes-Cantor distance and neighbour-joining methods. Bootstrap probabilities for the Brucella-Ochrobactrum cluster were more than $95 \%$. The scale bar represents 0.01 substitution per nucleotide position.
Table 3. Sequence signatures in the $16 \mathrm{~S}$ rDNAs of Brucella spp. and $O$. intermedium sp. nov.

\begin{tabular}{|lcccccc|}
\hline Species & \multicolumn{5}{c|}{ Nucleotide position* } \\
\cline { 2 - 7 } & $\mathbf{1 0 2 1}$ & $\mathbf{1 0 2 2}$ & $\mathbf{1 0 2 4}$ & $\mathbf{1 0 3 1}$ & $\mathbf{1 0 3 7}$ \\
\hline Brucella spp. & $\mathrm{A}$ & $\mathrm{C}$ & $\mathrm{A}$ & $\mathrm{A}$ & $\mathrm{C}$ \\
O. intermedium sp. nov. $\dagger$ & $\mathrm{A}$ & $\mathrm{C}$ & $\mathrm{A}$ & $\mathrm{C}$ & $\mathrm{T}$ \\
\hline
\end{tabular}

* E. coli numbering (Brosius et al., 1978); due to alignment gaps, nucleotides indicated for $E$. coli position 1031 could also correspond to position 1032 .

$\dagger O$. intermedium sp. nov. corresponds to the LMG 3301 cluster (see text for details).

and $100 \%$ and, because of this, not all the differences among species or strains were included in Fig. 4. Sequence signatures for Brucella spp. and for the LMG 3301 cluster are shown in Table 3 . No sequence signature existed at the same positions for the $O$. anthropi LMG $3331^{\mathrm{T}}$ cluster.

To ascertain whether the heterogeneity described above for the collection strains was also reflected in recent clinical isolates classified as $O$. anthropi (Holmes et al., 1988), the DNA of five such isolates was extracted and tested by PCR with primers amplifying a $905 \mathrm{~kb}$ fragment common to Brucella and O. anthropi LMG 3301 but absent from $O$. anthropi $\mathrm{LMG} 3331^{\mathrm{T}}$ (Romero et al., 1995). The results showed that three isolates (CUN 559, CUN 2944 and CUN 6130 strains, Table 1) belonged to the LMG 3301 cluster.

\section{Conventional phenotypical characterization}

Regardless of the hybridization group (Table 1), serological cross-reactivity and 16S rRNA cluster (see above), all Ochrobactrum strains tested had the following positive characteristics: growth at $37^{\circ} \mathrm{C}$ and at room temperature $\left(18-22^{\circ} \mathrm{C}\right)$; growth on MacConkey agar; presence of $1-3$ polar flagella, urease, catalase and cytochrome $\mathrm{C}$ oxidase activities; nitrate reduction; $\mathrm{H}_{2} \mathrm{~S}$ production; utilization of citrate, glycerol, and maltose; and enzymic hydrolysis of $p$-nitrophenyl $\alpha$ - $\beta$-glucoside, $p$-nitrophenyl phosphate, and $\gamma$-Lglutamyl $p$-nitroanilide.

All strains gave negative responses in the following tests: indole production; gelatinase, lysine decarboxylase, ornithine decarboxylase and arginine dihydrolase; utilization of arabinose, glucose, lactose, maltose, melibiose, mannitol, raffinose, sorbitol, saccharose, inositol, rhamnose and paracoumaric acid; hydrolysis of proline nitroanilide, $o$-nitrophenyl- $\beta$-D-galactoside, $p$-nitrophenyl- $\beta$-galactoside, $\quad p$-nitrophenylbisphosphate, $p$-nitrophenylxyloxide, $p$-nitrophenyl- $\beta$ glucuronide, $p$-nitrophenyl-phosphorylcholine, $p$ nitrophenyl- $N$-acetyl glucosaminide, $p$-nitrophenyl- $\alpha$ arabinoside, $p$-nitro-DL-phenylalanine; and assimilation of adipate, phenyl-acetate, 2,4,4'-trichloro-2'hydroxydiphenylether, acetamide and malonate.

Variable responses depending on the particular strain were observed in tetrazolium reduction, aesculin hydrolysis, caproate assimilation, polymyxin B susceptibility, and utilization of mannose, xylose and adonitol.

All strains tested were resistant to amoxicillin, 
ampicillin/clavulanic acid, aztreonam, ceftazidime, ceftriaxone, cephalotin, chloramphenicol and piperacillin. All were susceptible to gentamicin, ofloxacin and trimethoprim/sulfamethoxazole. The four strains clustering with $O$. anthropi $\mathrm{LMG} 3331^{\mathrm{T}}$ plus strains CUN 9446 and CUN 11040 (which were PCRnegative; see above) were clearly sensitive to colistin and polymyxin $\mathrm{B}$ with inhibition haloes greater than $20 \mathrm{~mm}$ in diameter. In contrast, strains LMG 3301 and 3306 and the related three clinical isolates (CUN 559, CUN 2944 and CUN 6130) were not inhibited by the same antibiotics at the highest concentration tested.

\section{DISCUSSION}

The results of this research showed an intense serological cross-reactivity between Brucella spp. and strains included in $O$. anthropi, and cross-reactivity with the agrobacteria was also observed. Moreover, coincidence between the analyses of the Western blots of whole-cell extracts and the 16S rRNA sequences was observed. Those results strengthen the position of the brucellae in a close relationship with soil bacteria and plant symbionts which had been shown by rRNA and lipid A analyses (De Ley et al., 1987; Moreno et al., 1990; Yanagi \& Yamasoto 1993), further support the definition of a new Ochrobactrum species [which was implicit in previous DNA hybridization studies (Holmes et al., 1988)], and show that the proposed new species is closer to the brucellae than to the $O$. anthropi type strain cluster.

Computer-assisted protein profiling has often been used as a complementary method for DNA and RNA taxonomic analysis (Vandamme et al., 1996). The usefulness of this approach is illustrated by the fact that, although only representative strains were tested, it suggested a differentiation of the classical Brucella spp. and a separation of $B$. suis and $B$. ovis from the $B$. melitensis- $B$. abortus subcluster in perfect agreement with restriction patterns (Allardet-Servent et al., 1988; Michaux-Charachon et al., 1997), ribotyping (Grimont et al., 1992), sequence analysis of the omp2 gene (Ficht et al., 1996) and numerical analysis of fatty acid profiles (Tanaka et al., 1977). A logical step forward is the combination of numerical analysis of protein patterns with the detection of the shared antigens by immunoenzymic methods. In the present study, this method allowed a more refined analysis of whole-cell extracts which yielded results consistent with those of the 16S rRNA and other analyses. Previous studies (Holmes et al., 1988) have shown that $B$. abortus and $O$. anthropi hybridization groups 1 (strain LMG $3331^{\mathrm{T}}$ ) and 2 (strain LMG 3301) show 20-30\% and 14-28\% DNA homology, respectively, a result that does not allow assessment of the relative distances. However, perusal of the literature reveals that some of the strains used to define $O$. anthropi (Holmes et al., 1988) had also been used in rRNADNA hybridization studies (De Ley et al., 1987), and that these studies had already suggested a closer relationship of the strains included in hybridization group 2 and the brucellae. Obviously, these data are confirmed and extended by the results of the present study.

The results obtained in the numerical analysis of Western blots of whole-cell extracts were not reproduced when the same procedure was applied to the soluble fractions. In particular, the brucellae and the $O$. anthropi strains were not resolved numerically. However, since genus-specific proteins were conspicuous by Western blot, it could be that the profiles were too simple. [It is not illogical that numerical analysis should be more meaningful with more complex extracts (i.e. whole-cell extracts) than with subcellular (i.e. soluble) fractions.] Interestingly, the number of common components detected by IEP with soluble fractions was consistently higher than that obtained by Western blot. Since gel immunoprecipitations and Western blots preferentially detect antibodies to conformational and linear epitopes (Butler, 1991), respectively, the results show that a greater number of epitopes of the former type are shared by soluble proteins of closely related bacteria. This same conclusion is reached when the results obtained with the agrobacteria are compared: whereas cross-reactivity with either Brucella or Ochrobactrum was negligible in Western blot, IEP detected several conspicuous common components. Thus, it seems likely that numerical analysis of Western blot profiles is most useful when closely related bacteria are studied, whereas methods detecting conformational epitopes show relatedness over a wider taxonomic range.

Finally, the results of this and previous works (De Ley et al., 1987; Holmes et al., 1988; Romero et al., 1995) show that the taxonomic status of bacteria routinely classified as $O$. anthropi on the basis of conventional tests (Bizet \& Bizet, 1995; Brivet et al., 1993; Chang et al., 1996; Cieslak et al., 1992; Ezzedine et al., 1994; Grandsden \& Eykyn, 1992; Haditsch et al., 1994) should be revised. According to currently accepted criteria (Stackebrandt \& Goebel, 1994), the degree of internal DNA-DNA homology of hybridization group 2 (relative binding ratio from 73 to $96 \%$ ) (Homes et al., 1988), the relatively low crosshybridization with group 1 (from 41 to $51 \%$ ), and the closer similarity (16S rRNA, and Western blot of whole-cell proteins) of hybridization group 2 to the Brucella spp. all show that the LMG 3301 cluster should be given a separate species status for which the name of $O$. intermedium (of intermediate position between $O$. anthropi and Brucella spp.) is proposed (see description below). Furthermore, in the light of the new methods of analysis, the biotypes (A, C and D) proposed for $O$. anthropi (Holmes et al., 1988) have no taxonomic value because biotype A would include this new species and most of the classical strains. Unfortunately, the classical morphological and physiological tests examined in this work and in the work of Holmes et al. (1988) do not show a phenotypic pattern useful to discriminate the two Ochrobactrum groups. However, the LMG 3301 cluster was readily 
discriminated by PCR with the primers described. In addition, although this should be confirmed with a larger number of strains, colistin resistance and sensitivity correctly grouped, respectively, the 12 strains examined as either $O$. intermedium (5 strains) or $O$. anthropi. Colistin (polymyxin $\mathrm{E}$ ) is a polycationic lipopeptide and it is interesting that a trait of the brucellae is their comparative resistance to polycationic peptides including polymyxins (Freer et al., 1996; Martínez de Tejada et al., 1995). In Gramnegative bacteria, this resistance occurs by reduced or no binding of the peptides to the lipopolysaccharide (the target in susceptible bacteria) caused by peculiarities in the lipid A-core chemical structure (Vaara, 1992). Thus, consistent with the results discussed above, the resistance to colistin is likely to mark a structural difference between $O$. anthropi and $O$. intermedium which would also indicate similarity of the latter to the brucellae.

\section{Description of Ochrobactrum intermedium sp. nov.}

Ochrobactrum intermedium (in'ter.me'dium. L. neut. adj. intermedium of intermediate position).

The description is taken from the results of this work and that of Holmes et al. (1988), and is based on the data obtained with five strains (LMG 3301, LMG 3306, CUN 559, CUN 2944 and CUN 6130, Table 1). The cells are rod-shaped, usually occur singly, and are motile by 1-3 polar or subpolar flagella. After growth on nutrient agar for $24 \mathrm{~h}$ at $37^{\circ} \mathrm{C}$, colonies are typically circular, low convex, about $1 \mathrm{~mm}$ in diameter, smooth, shining and entire. A total of 47 characteristics are common to the five strains tested (either positive or negative). The cells have the following positive characteristics: growth at $37^{\circ} \mathrm{C}$; growth at room temperature $\left(18-22^{\circ} \mathrm{C}\right)$; growth on MacConkey agar; and cytochrome- $c$ oxidase activities; nitrate reduction, $\mathrm{SH}_{2}$ production; utilization of citrate, glycerol and maltose; and enzymic hydrolysis of $p$-nitrophenyl $\alpha-\beta$ glucoside, $p$-nitrophenyl phosphate and $\gamma$-L-glutamyl $p$-nitroanilide. All the strains gave negative responses in the following tests: indole production; gelatinase, lysine and ornithine decarboxylase, and arginine dihydrolase activities; utilization of arabinose, glucose, lactose, maltose, melibiose, mannitol, raffinose, sorbitol, saccharose, inositol, rhamnose and paracoumaric acid; enzymic hydrolysis of proline nitroanilide, $o$-nitrophenyl-galactoside, $p$-nitrophenyl$\beta$-galactoside, $p$-nitrophenyl-bisphosphate, $p$-nitrophenyl-xyloxide, $\quad p$-nitrophenyl- $\beta$-glucuronide, $\quad p$ nitrophenyl-phosphoryl-choline, $\quad p$-nitrophenyl- $\beta-N$ acetylglucosaminide, $p$-nitrophenyl- $\alpha$-arabinoside, $p$ nitro-DL-phenylalanine and esculine; and assimilation of adipate, phenyl-acetate, 2,4,4'-trichloro-2'-hidroxydiphenylether, acetamide and malonate. In contrast to seven $O$. anthropi strains tested, five strains of the proposed new species were resistant to colistin. Moreover, PCR test with primers F4 (5'-TCGAGCGCCCGCAAGGG-3') and R2 (5'-AACCATAGTGTCTCCACTAA- $3^{\prime}$ ) are positive with $O$. intermedium and negative with $O$. anthropi (Romero et al., 1995). The $\mathrm{G}+\mathrm{C}$ content of the DNAs of strains LMG 3301 and 3306 are between 57.7 and $58.3 \mathrm{~mol} \%$. The type strain is LMG $3301^{\mathrm{T}}\left(=\right.$ NCTC $12171^{\mathrm{T}}=$ CNS $\left.2-75^{\mathrm{T}}\right)$.

\section{ACKNOWLEDGEMENTS}

We are indebted to Dra Milagros López for providing the Agrobacterium strains used in this work. This research was supported by the Dirección General de Investigación Científica y Tecnológica (AGF95-1013-CO2 and BIO961398-CO2). Fellowship support for J.V. from the Ministerio de Educación, Ciencia y Tecnología of Spain, and for C.R. from the Friends of the University of Navarra is gratefully acknowledged.

\section{REFERENCES}

Aguillera, M. M., Hodge, N. C., Stall, R. E. \& Smart, G. C., Jr (1993). Bacterial symbionts of Steinernema scapterisci. J Invertebr Pathol 68, 68-72.

Allardet-Servent, A., Bourg, G., Ramuz, M., Pages, M., Bellis, M. \& Roizes, G. (1988). DNA polymorphism in strains of the genus Brucella. J Bacteriol 170, 4603-4607.

Alton, G. G., Jones, L. M., Angus, R. D. \& Verger, J. M. (1988). Techniques for the Brucellosis Laboratory. Paris: INRA.

Aragón, V., Dlaz, R., Moreno, E. \& Moriyón, I. (1996). Characterization of Brucella abortus and Brucella melitensis native haptens as outer membrane O-type polysaccharides independent from the smooth lipopolysaccharide. $J$ Bacteriol 178, 1070-1079.

Bauer, A. W., Kirby, W. M. M., Sherris, J. C. \& Turck, M. (1966). Antibiotic susceptibility testing by a standardized single disk method. Am J Clin Pathol 45, 493-496.

Bizet, C. \& Bizet, J. (1995). Sensibilité comparée de Ochrobactrum anthropi, Agrobacterium tumefaciens, Alcaligenes faecalis, Alcaligenes denitrificans subsp. denitrificans, Alcaligenes denitrificans subsp. xylososidans et Bordetella bronchiseptica visà-vis de 35 antibiotiques dont 17 beta-lactamines. Pathol Biol 43, 258-263.

Brivet, F., Guibert, M., Kiredjian, M. \& Dormont, J. (1993). Necrotizing fasciitis, bacteremia, and multiorgan failure caused by Ochrobactrum anthropi. Clin Infect Dis 17, 516-518.

Brosius, J., Palmer, M. L., Kennedy, P. J. \& Noller, H. F. (1978). Complete nucleotide sequence of a $16 \mathrm{~S}$ ribosomal RNA gene from E. coli. Proc Natl Acad Sci USA 75, 4801-4805.

Butler, J. E. (1991). Perspectives, configurations and principles. In Immunochemistry of Solid-phase Immunoassay, pp. 3-27. Edited by J. E. Butler. Boca Raton, FL: CRC Press.

Chang, H. J., Christenson, J. C., Pavia, A. T. \& 11 other authors (1996). Ochrobactrum anthropi meningitis in pediatric pericardial allograft transplant recipients. $J$ Infect Dis 173, 656-660.

Cieslak, T. J., Robb, M. L., Drabick, C. J. \& Fischer, G. W. (1992). Catheter-associated sepsis caused by Ochrobactrum anthropi: report of a case and review of related nonfermentative bacteria. Clin Infect Dis 14, 902-907.

De Ley, J., Mannheim, W., Segers, P., Lievens, A., Denjin, M., Vanhoucke, M. \& Gillis, M. (1987). Ribosomal ribonucleic acid cistron similarities and taxonomic neighborhood of Brucella and CDC group Vd. Int $J$ Syst Bacteriol 37, 35-42.

Díaz, R., Jones, L. M. \& Wilson, J. B. (1966). Antigenic relationship of Brucella ovis and Brucella melitensis. $J$ Bacteriol 93, 1262-1268. 
Diaz, R., Jones, L. M. \& Wilson, J. B. (1968). Antigenic relationship of the gram-negative organism causing canine abortion to smooth and rough brucellae. J Bacteriol 95, 618-624.

Dorsch, M., Moreno, E. \& Stackebrandt, E. (1989). Nucleotide sequence of the 16S rRNA from Brucella abortus. Nucleic Acids Res 17, 1765.

Edwards, U., Rogall, T., Blöcker, H., Emde, M. \& Böttger, E. C. (1989). Isolation and direct complete nucleotide determination of entire genes. Characterization of a gene coding for $16 \mathrm{~S}$ ribosomal RNA. Nucleic Acid Res 17, 7843-7853.

Ezzedine, H., Mouraud, M., Van Ossel, C., Logghe, C., Squifflet, J. P., Renault, F., Wauters, G., Gigi, J., Wilmotte, L. \& Haxhe, J. J. (1994). An outbreak of Ochrobactrum anthropi bacteremia in five organ transplant patients. $J$ Hosp Infect 27, 35-42.

Felsenstein, J. (1993). PHYLIP (Phylogeny Inference Package) $3.5 \mathrm{c}$ Department of Genetics, University of Washington, Seattle, USA (distributed by the author).

Ficht, T. A., Husseinen, H. S., Derr, J. \& Bearden, S. W. (1996). Species-specific sequences at the omp2 locus of Brucella type strains. Int J Syst Bacteriol 46, 329-331.

Freer, E., Moreno, E., Moriyón, I., Pizarro-Cerdá, J., Weintraub, A. \& Gorvel, J. P. (1996). Brucella/Salmonella-lipopolysaccharide chimeras are less permeable to hydrophobic probes and more sensitive to cationic peptides and EDTA than their native Brucella spp. counterparts. J Bacteriol 178, 5867-5876.

García-Carrillo, C. \& Casas-Olascoaga, R. (1977). Comparison of two challenge strains used to test the potency of Brucella abortus vaccines. $\mathrm{Br}$ Vet $J 133,554-558$.

Grandsden, W. R. \& Eykyn, S. J. (1992). Seven cases of bacteremia due to Ochrobactrum anthropi. Clin Infect Dis 15, 1068-1069.

Griffiths, E. \& Humphreys, J. (1978). Alterations in t-RNAs countering 2-methylthio- ${ }^{6} \mathrm{~N}-\left({ }^{2} \mathrm{~d}\right.$-isopentenyl)-adenosine during growth of enteropathogenic Escherichia coli in the presence of iron binding proteins. Eur J Biochem 82, 503-513.

Grimont, F., Verger, J. M., Cornelis, P., Limet, J., Lefèvre, M., Grayon, M., Régnault, B., Van Broeck, J. \& Grimont, P. A. D. (1992). Molecular typing of Brucella with cloned DNA probes. Res Microbiol 143, 55-65.

Haditsch, M., Binder, L., Tschurtschenthaler, G., Watschinger, R., Zauner, G. \& Mittermayer, H. (1994). Bacteriemia caused by Ochrobactrum anthropi in an immunocompromised child. Infection 22, 291-292.

Hawkes, R., Niday, E. \& Gordon, J. (1982). A dot-immunobinding assay for monoclonal and other antibodies. Anal Biochem 119 , 142-147.

Holmes, B., Popoff, M., Kiredjian, M. \& Kersters, K. (1988). Ochrobactrum anthropi gen. nov., sp. nov. from human clinical specimens and previously known as Group Vd. Int J Syst Bacteriol 38, $406-416$.

Martínez de Tejada, G., Pizarro-Cerdá, J., Moreno, E. \& Moriyón, I. (1995). The outer membranes of Brucella spp. are resistant to bactericidal cationic peptides. Infect Immun 63, 3054-3061.

McEwen, A. D. (1940). The virulence of B. abortus for laboratory animals and pregnant cattle. Vet Rec 52, 97-106.

Michaux-Charachon, S., Bourg, G., Jumas-Bilak, E., Guigue-Talet, P., Allardet-Servent, A., O'Callaghan, D. \& Ramuz, M. (1997). Genome structure and phylogeny in the genus Brucella. $J$ Bacteriol 179, 3244-3249.

Moreno, E. (1992). Evolution of Brucella. In Advances in
Brucellosis Research, pp. 198-218. Edited by M. Plommet. Wageningen: Pudoc Scientific Publishers.

Moreno, E., Stackebrandt, E., Dorsch, M., Wolters, J., Busch, M. \& Mayer, H. (1990). Brucella abortus 16S RNA and lipid A reveal a phylogenetic relationship with members of the $\alpha-2$ subdivision of the class Proteobacteria. J Bacteriol 172, 3569-3576.

Moriyón, I. \& Berman, D. T. (1982). Effects of nonionic, ionic and dipolar ionic detergents and EDTA on Brucella cell envelopes. $J$ Bacteriol 152, 822-828.

National Committee for Clinical Laboratory Standards (1997). Performance Standards for Antimicrobial Disk Susceptibility Tests, 6th edn. Approved Standard M2-A6. Wayne, PA: NCCLS.

Pot, B., Vandamme, P. \& Kersters, K. (1994). Analysis of electrophoretic whole-organism protein fingerprinting. In Modern Microbial Methods. Chemical Methods in Bacterial Systematics, pp. 493-521. Edited by M. Goodfellow \& A. G. O'Donnell. Chichester: Wiley.

Rolfs, A., Schuller, I., Finckh, U. \& Weber-Rolfs, I. (1992). PCR: clinical diagnostic and research. Springer, Berlin.

Romero, C., Gamazo, C., Pardo, M. \&. López-Goñi, I. (1995). Specific detection of Brucella DNA by PCR. J Clin Microbiol 33, 615-617.

Schurig, G. G., Roop, R. M., II, Bagchi, T., Boyle, S., Buhrman, D. \& Sriranganathan, N. (1991). Biological properties of RB51; a stable rough strain of Brucella abortus. Vet Microbiol 28, 171-188.

Stackebrandt, E. \& Goebel, B. M. (1994). Taxonomic note: a place for DNA-DNA reassociation and 16S rRNA sequence analysis in the present species definition in bacteriology. Int $J$ Syst Bacteriol 44, 846-849.

Tanaka, S., Suto, T., Isayama, Y., Azuma, R. \& Hatakeyama, H. (1977). Chemo-taxonomical studies on fatty acids of Brucella species. Ann Sclavo 19, 67-82.

Vaara, M. (1992). Agents that increase the permeability of the outer membrane. Microbiol Rev 56, 395-411.

Vandamme, P., Pot, B., Gillis, M., de Vos, P., Kersters, K. \& Swings, J. (1996). Polyphasic taxonomy, a consensus approach to bacterial systematics. Microbiol Rev 60, 407-438.

Vauterin, L. \& Vauterin, P. (1992). Computer-aided objective comparison of electrophoresis patterns for grouping and identification of microorganisms. Eur Microbiol 1, 37-41.

Velasco, J., Dłaz, R., Barberán, M., Grilló, M. J., Marín, C., Blasco, J. M. \& Moriyón, I. (1997). Antibody and delayed type hypersensitivity responses to Ochrobactrum anthropi cytosolic and outer membrane antigens in infections by smooth and rough Brucella spp. Clin Diagn Lab Immunol 4, 279-284.

Verger, J. M., Grimot, D., Grimont, P. A. D. \& Grayon, M. (1985). Brucella a nonspecific genus as shown by deoxyribonucleic acid hybridization. Int J Syst Bacteriol 35, 292-295.

Weisburg, W. G., Barns, S. M., Pelletier, D. A. \& Lane, D. J. (1991). $16 \mathrm{~S}$ ribosomal DNA amplification for phylogenetic study. $J$ Bacteriol 173, 697-703.

Xin, X. (1986). Orally administrable brucellosis vaccine: $B$. suis strain 2 vaccine. Vaccine 4, 212-216.

Yanagi, M. \& Yamasoto, K. (1993). Phylogenetic analysis of the family Rhizobiaceae and related bacteria by sequencing of $16 \mathrm{~S}$ rRNA gene using PCR and DNA sequencer. FEMS Microbiol Lett 107, 115-120. 